\title{
Lumen
}

Selected Proceedings from the Canadian Society for Eighteenth-Century Studies

\section{Spirituality and Practicality: John Wesley's visit to America and Moravian Influences on Methodist Music and Worship}

\section{Martin V. Clarke}

Volume 27, 2008

North America at the Crossroads of European Cultures in the Eighteenth Century

L’Amérique du Nord au Carrefour des cultures au XVIII ${ }^{\mathrm{e}}$ siècle

URI : https://id.erudit.org/iderudit/1012047ar

DOI : https://doi.org/10.7202/1012047ar

Aller au sommaire du numéro

Éditeur(s)

Canadian Society for Eighteenth-Century Studies / Société canadienne d'étude du dix-huitième siècle

ISSN

1209-3696 (imprimé)

1927-8284 (numérique)

Découvrir la revue

Citer cet article

Clarke, M. V. (2008). Spirituality and Practicality: John Wesley's visit to America and Moravian Influences on Methodist Music and Worship. Lumen, 27, 13-26. https://doi.org/10.7202/1012047ar

Copyright (C Canadian Society for Eighteenth-Century Studies / Sociéte canadienne d'étude du dix-huitième siècle, 2009
Ce document est protégé par la loi sur le droit d'auteur. L'utilisation des services d'Érudit (y compris la reproduction) est assujettie à sa politique d'utilisation que vous pouvez consulter en ligne.

https://apropos.erudit.org/fr/usagers/politique-dutilisation/ 


\section{Spirituality and Practicality: John Wesley's visit to America and Moravian Influences on Methodist Music and Worship}

John Wesley's voyage to Georgia in 1735-36 is often represented as one of the most significant events in the early history of the Methodist movement prior to his famous conversion experience of 24 May, $1738 .{ }^{1}$ Wesley's admiration of the faith of the Moravian Christians he met on board the Simmonds is recorded in his diaries and journal during this period and the enduring influence of Moravian thought and practice is commonly regarded as the most positive aspect of his voyage and missionary work in America. Ralph Waller comments that "This voyage to Georgia has become a central part of the Methodist story. There seems little doubt that Wesley learnt from the example of the Moravians: to the young Oxford don they were a shining example of Christian service and trust in God." ${ }^{2}$

From the Moravians, Wesley learnt much about church organization, structure, worship and hymnody; elements that were to leave a lasting impression on the Methodist movement, often evolving into a uniquely Methodist expression. With regard to worship, hymnody, and music in particular, these influences need to be considered in theological terms, taking into account Moravian theological understanding, the ways in which these facets were shaped by Wesley and the Methodists, and in

1 While attending a religious meeting at Aldersgate Street, Wesley records how he felt his heart "strangely warmed" and received the assurance of forgiveness and salvation. Ralph Waller, John Wesley : A Personal Portrait (London: SPCK, 2003), 49.

2 Ibid, 34. 
relation to more recent, broader theological approaches to music, especially within a congregational context.

\section{Moravian Religious Practice and Theology}

Moravian expressions of religion were defined by a strong emphasis on communality among believers and significant congregational participation; attendance at particular religious meetings and participation in certain rituals were subject to provisos concerning the faith and commitment of individual believers. Small, intimate gatherings for fellowship, prayer and study were commonplace within the Moravian communities and attempted to encourage a sense of religious duty in all areas of life. Hymnody featured prominently in Moravian worship and other meetings, both as an obvious practical means of allowing the whole gathering to participate but also as a significant aid to theological expression, education and understanding.

Since the earliest days of the Unitas Fratum, worship in the language of the people has been of central importance to Moravians. A second guiding principle, that of congregational participation in worship, has worked with the former to make hymn singing an integral part of Moravian worship. Hymn singing to Moravians provides both a vehicle for, and evidence of, that fellowship with each other and with the Lord which is so dear. ${ }^{3}$

Eighteenth-century Moravianism was dominated by the religious community established at Herrnhut, under the guidance of Nicholas Ludwig von Zinzendorf. ${ }^{4}$ His wealth and aristocratic status influenced many aspects of Moravian life, including its music, which gained a high reputation. In England, musicians were employed and organs constructed at Moravian places of worship, but despite attracting favourable comment from musicians and prominent members of society, a strong emphasis was placed on the proper function of music within

3 Albert H. Frank, Companion to the 1995 Moravian Book of Worship (Winston-Salem, N.C.: Moravian Music Foundation, 2004), 1.

4 Zinzendorf, an imperial nobleman, founded the Renewed Moravian Church in the early 1720s. He made a huge contribution to Moravian worship and hymnody: "To Zinzendorf, singing had above all to express Christian experience. He himself wrote some 2000 hymns and stimulated others to write." John R. Weinlick, "Zinzendorf, Nikolaus Ludwig Von," in The New Grove Dictionary of Music and Musicians, ed. S. Sadie and J. Tyrrell (London: Macmillan, 2001), 849. 
a worshipful context and measures were put in place to dissuade those attracted only by the music. ${ }^{5}$ This emphasis on music's role as a fully integrated aspect of worship rather than to give purely aesthetic pleasure accords with the Moravian understanding that all aspects of life should reflect religious values: "According to Zinzendorf and the Moravians of his time, every aspect of daily life, even its most mundane elements, could be regarded as 'liturgical', that is, as a type of worship to be offered to God, after the example of Christ himself." ${ }^{\prime 6}$

However, this conservatism over admitting people to worship on a more speculative basis illustrates another distinctive aspect of Moravian theology, the doctrine of stillness. This advocated a severely limited religious involvement for those who had not yet reached a fully-developed personal faith: "The kernel of the idea of stillness was that those who did not yet have faith should 'be still', that is, abstain from Communion and even from excessive prayer, Bible reading, and attendance at church." ${ }^{\prime 7}$ Religious events such as Band Meetings and Love Feasts were also restricted to full members of the community. Thus although Moravianism encouraged communal forms of religion, its restrictive attitude towards participation reflected a theological position that would ultimately cause a schism with Wesley and the Methodists, although underlying principles were to remain influential after this separation.

\section{Wesley's Appropriation of Moravian Models within Methodism}

The beginnings of Methodism as a movement intended to supplement the regular religious life of the parish system meant that a strong emphasis was placed on regular fellowship among the local members. Wesley had observed the model of an Anglican Religious Society at Epworth, and although this extension of parish life is clearly connected to the societal organisation of Methodism into class meetings, the influence of Moravian practice was to shape it further, at a yet more localised level;

5 In 1747-48, the Moravian Community in London limited musical accompaniment to the organ only, included long hymns to emphasise that it was the theological message of the hymn text that took precedence, and even temporarily suspended the use of music. Colin Podmore, The Moravian Church in England, 1728-1760 (Oxford, New York: Clarendon Press; Oxford University Press, 1998), 151.

6 Nola Reed Knouse, "Moravians, Music of The," in The New Grove Dictionary of Music and Musicians, ed. S. Sadie and J. Tyrrell (London: Macmillan, 2001), vol. 17, 97. 
each society was subdivided into smaller bands, which were lay-led by both male and female members:

John Wesley borrowed the idea of bands from the Moravians. A band, of five to ten people, was smaller than the more relaxed class meeting, and meant to be more intense. Men, women, the married and the single met in separate bands once a week, confessed their sins and prayed for one another. Critics regarded bands as the Catholic confessional in another form. ${ }^{8}$

This practice became one of the most distinctive features of Methodism and was upheld as a necessary means of ensuring that members adhered to Christian principles in their everyday lives and took part in the corporate religious responsibilities of the whole community. Likewise, the Love Feast became a distinctive feature of communal religious life within the Methodist Societies, usually taking place on a quarterly basis and although originally open only to those belonging to bands, later came to involve the whole society, though divided into groups based on gender and marital status. A simple meal of plain cake and water was partaken and the sharing of testimony also featured prominently. Kent describes the "intense communal pressure" of such gatherings", and it is clear that the attraction of this practice to Wesley and its popularity within Methodism lay in the deeply spiritual experience it engendered in many of the participants as they recounted the "blessings they had found lately"10 and took inspiration from each other. Wesley's admiration of this form of religious expression stemmed from his understanding of it as a re-creation of the practices of the early Church: "[Wesley] refers to the Love-feast by the name used by the early Church - Agape."11

Although, over the course of time, Wesley moved away from the Moravians on theological grounds, these practical expressions of communal spirituality survived and became firmly embedded within the life and worship of Methodism. Theological differences did not affect the applicability of such models to the Methodist Societies, even

8 John Kent, Wesley and the Wesleyans : Religion in Eighteenth-Century Britain (Cambridge: Cambridge University Press, 2002), 216 n.23.

9 Ibid, 15.

10 Cited in Clifford W. Towlson, Moravian and Methodist: Relationships and Influences in the Eighteenth Century (London: Epworth Press, 1957), 213.

11 Ibid, 210. 
though they dictated the detail as well as the principle in their original Moravian context. Although impressed with the communal discipline of the Moravians, Wesley objected to the doctrine of stillness that had come to dominate their spiritual life; this advocated that humans could do nothing to earn God's grace, but wait until they gained a fuller understanding of the faith.

Although membership of the Methodist Bands and attendance at the Love Feasts demanded a particular commitment from individuals, once believers had joined the society, they were encouraged to participate in such activities in order to sustain and strengthen their faith. Thus, the continued use of Moravian practices in Methodist life represents a divorcing of the practice from the associated beliefs of their original context and a transformation into a uniquely Methodist understanding of religious life and faith.

\section{Moravian Hymnody as Theological Expression}

As indicated above, hymnody played an important role in Moravian religious life and came to exert a profound influence on Wesley in both thought and practice. Moravian hymnals date back to the very beginning of the sixteenth century and are among the first recorded Protestant hymnals. Hymn singing formed a large part of the devotional life of the community at Herrnhut, where Wesley visited, and many texts date from the revival there in the second quarter of the eighteenth century. Zinzendorf introduced Singstunde, which were free sessions of hymn singing, designed to strengthen the congregation: "He felt that they were ways to a genuine expression of enthusiastic pietistic faith and therefore a measure of the spiritual condition of the congregation. ${ }^{12}$ The Singstunde became a central part of Moravian life, a service in which stanzas from the hymnal would be selected for singing in order to explore a particular aspect of the Christian faith. Hymn singing also featured prominently in other forms of worship, including communion, with the hymns always chosen to emphasise the significance of the occasion. Colin Podmore comments that under Zinzendorf's guidance, "Moravian life was increasingly marked by festivity and celebration, music, art, colour and light."

12 Walter Blankenburg, "The Music of the Bohemian Brethren," in Protestant Church Music : A History, ed. Friedrich Blume (London: Gollancz, 1975), 600.

13 Podmore, The Moravian Church in England, 1728-1760, 17. 
Zinzendorf's advocacy of this frequent use of hymnody is highly symptomatic of the dual understanding of hymnody's function that characterised Moravian worship and spiritual life, and was to determine Wesley's approach to hymnody and its use within the Methodist movement. Although the hymnody acted most obviously as a uniting, corporate act of praise, encouraging full congregational participation, more significantly, it also fulfilled a pedagogical function, embodying a particular theological interpretation of scripture, corresponding to that which was preached to the congregation, thus reinforcing these beliefs and attempting to strengthen their faith within a particular religious tradition. Albert Frank argues that hymnody, both in concept and content, embodies Moravian religious belief: "Hymns connect Moravians to their heritage, yet they place worshippers squarely in the present. They provide the clearest and most public expressions of Moravian theology as well as the deepest heart-felt responses to God."14 Although theological differences ultimately led to a breakdown in the relationship between the Moravians and Methodists, this understanding of the role of hymnody persisted within Methodist worship, developing into a unique expression of theological beliefs and corporate praise.

\section{The Theological Significance of Moravian Influences on Methodist Hymnody: Text, Music and Understanding}

Beginning on the voyage to America and over the ensuing four years, John Wesley translated thirty-six German hymns, learnt from his contact with the Moravians. ${ }^{15}$ The hymns he chose to translate embody a strong theological message, at once praising God for his grace, and explaining its significance to those who sang or heard the hymns. The notion of grace freely offered underpinned Methodism's entire theological position and is most cogently expressed in many hymns by Charles Wesley. This direct connection with the content of Moravian hymnody was obviously the prime reason that John Wesley found them so appealing and the development of this aspect of the hymns into an idiomatically Methodist style owes much to Moravian practice in the field.

In keeping with the Moravian understanding of hymnody, the hymns Wesley chose to translate have a dual purpose, at once both evangelistic and consolidating, designed to communicate both to those who were

14 Frank, Companion to the 1995 Moravian Book of Worship, 1.

- 15 The first translation is recorded in his diary on 5 May 1736. 
established members of the societies, and also those beyond the societies, to whom Methodism was seeking to appeal. John Wesley's translation of "Eternal depth of love divine"16 and Charles Wesley's hymn "All praise to our redeeming Lord"17 ${ }^{\prime 17}$ respectively illustrate the Moravian origin of this approach to hymnody and its later development within Methodism. Both contain statements of praise but also relate the significance of God's grace to the individual believer, but within the broader context of the worshipping community as a whole. The latter's frequent use of "all" with reference to the worshipping community represents a distinctively Methodist approach to the evangelistic capacity of hymnody by affirming the participation of all members of the congregation both in the present act of singing and in the spiritual realm described in the hymn.

Eternal depth of love divine, In Jesus, God with us, displayed;

How bright thy beaming glories shine!

How wide thy healing streams are spread! Together seek his face.

With whom dost thou delight to dwell? Sinners, a vile and thankless race;

O God, what tongue aright can tell

How vast thy love, how great thy grace!

The dictates of thy sovereign will With joy our grateful hearts receive;

All thy delight in us fulfil;

Lo! All we are to thee we give.

To thy sure love, thy tender care, Our flesh, soul, spirit, we resign: O fix thy sacred presence there, And seal the abode for ever thine!

O King of Glory! Thy rich grace Our feeble thought surpasses far;
All praise to our redeeming Lord, Who joins us by his grace;

And bids us, each to each restored,

He bids us build each other up;

And, gathered into one, To our high calling's glorious hope, We hand in hand go on.

The gift which he on one bestows, We all delight to prove;

The grace through every vessel flows, In purest streams of love.

Ev'n now we think and speak the same, And cordially agree;

Concentered all, through Jesu's Name, In perfect harmony.

We all partake the joy of one;

The common peace we feel;

16 Originally by Zinzendorf, Wesley's translation was first published in 1739.

17 First published in Hymns for those that seek and those that have Redemption in the Blood of Jesus Christ (1747). 
Yea, even our sins, though numberless, Less numerous than thy mercies are.

Still, Lord, thy saving health display, And arm our souls with heavenly zeal; So fearless shall we urge our way Through all the powers of earth and hell. ${ }^{11}$
A peace to sensual minds unknown, A joy unspeakable.

And if our fellowship below In Jesus be so sweet, What height of rapture shall we know When round His throne we meet! ${ }^{19}$

In addition to specific textual translations and more general textual influences, the music of Moravian hymnody also exerted a two-fold influence on Methodist practice, which needs to be interpreted within a theological context.

Wesley's first collection of hymn tunes, A Collection of Tunes, Set to Music, As they are commonly Sung at the Foundery $(1742)^{20}$ contains fortytwo tunes, of which thirteen are of confirmed German origin. Although these cannot be categorised as specifically Moravian, as several of them pre-date the establishment of Zinzendorf's community at Herrnhut, it was through the Moravian community that they were introduced to Wesley and thus transmitted to Methodism. This high proportion of tunes of German origin, several of which had not previously been included in a British publication, indicates that Wesley admired the musical as well as the textual qualities of Moravian hymnody; Clifford Towlson argues that the musical influence of Moravianism on Wesley should be considered among the most significant aspects of his contact with them: "it was the sublime achievement of the Moravians that they introduced him, and through him thousands of his followers, to the beauty, the dignity, the reverence, the fitness of the German chorale, and to the personal and intimate song of the great Pietists." ${ }^{21}$

18 Nicholas Ludwig von Zinzendorf and John Wesley, "Eternal Depth of Love Divine," in Hymns and Psalms : A Methodist and Ecumenical Hymn-Book (London: Methodist Publishing House, 1983), Hymn 34.

19 Charles Wesley, "All Praise to Our Redeeming Lord," in Hymns and Psalms : A Methodist and Ecumenical Hymn-Book (London: Methodist Publishing House, 1983), Hymn 753.

20 John Wesley, A Collection of Tunes, Set to Music. As They Are Commonly Sung at the Foundery, ed. Bryan F. Spinney, Facsimile reprint, 1981 ed. (London: John Pearson, 1742). Hereafter The Foundery Collection.

21 Towlson, Moravian and Methodist : Relationships and Influences in the Eighteenth Century, 195. 
The inclusion of these tunes may be accounted for on practical grounds; two of the five 8.8.8.8.8.8. metre tunes in the collection are of German origin, and thus provide much needed musical accompaniment to some of Charles Wesley's most popular and powerful hymn texts. ${ }^{22}$ The overall range of metres represented by the German tunes is comparatively large, adding breadth to the musical material of the collection. Musically, too, these tunes commend themselves; they are all set in a more sensible range for congregational singing than several of the tunes from other sources. The editorial quality of these tunes is consistently higher than is evinced among the remainder of the contents, suggesting that Wesley had obtained these from reliable sources, specifically designed for congregational use.

Here, the German tune, "Hemdyke Tune", may be usefully contrasted with the version of the March tune from Handel's Richard I, labelled "Jericho Tune" by Wesley. The former is clearly suitable for congregational singing, while the latter has been copied from the Violin I part of the score, without any concession to the range of the untrained musical voice. [See Figures 1 and 2]

The inherent superiority of the former for congregational singing is abundantly apparent from even the simplest analysis of these two tunes. The length of "Jericho Tune", which is structured in double verses of Double Short Metre ${ }^{23}$, suggests that it would be difficult to teach to a musically untrained congregation, even making using of the liningout technique. ${ }^{24}$ The absurd pitch may be discounted as bad editorial practice and could be easily rectified in performance, but the complexity of the melody still places severe musical demands on the singers. The time signature indicates a minim pulse, which, combined with the original context of the tune as a march, suggests a lively tempo. In light of this, the rhythmic figurations of the third system, the large leaps of the second half of the melody, the tonal complexity of modulations to the dominant and supertonic minor, and the frequent prolongation of

22 For example, "And can it be that I should gain/an interest in the Saviour's blood" and "Come, O thou Traveller unknown/Whom still I hold, but cannot see!"

23 Syllabic construction of Double Short Metre: 6.6.8.6.6.6.8.6. In this case, this pattern occurs twice within one complete repetition of the melody.

24 A process whereby each line of the hymn is first sung by a cantor then repeated by the congregation. In this instance, the sheer length of the tune would make this method both laborious and of limited value, as the volume of music to be retained in the memory is so large. 
fericbo Tune. Vol. 1. Page 141.
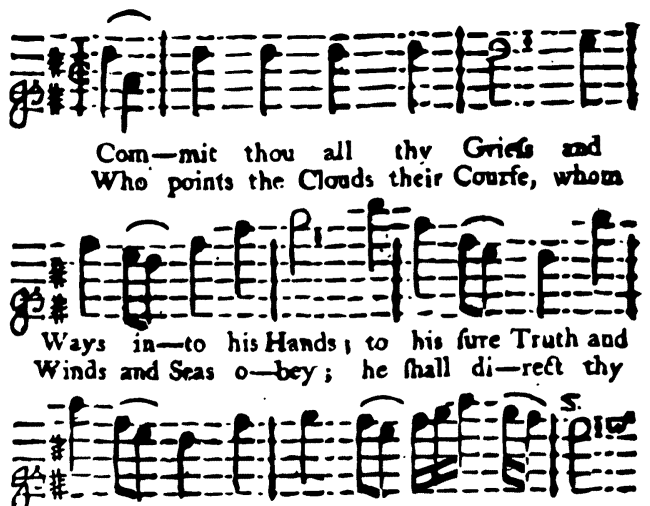

ten- der Care, who Barch and Heav'n commands. wand'ring Feet, he fall pre-pare the Way.

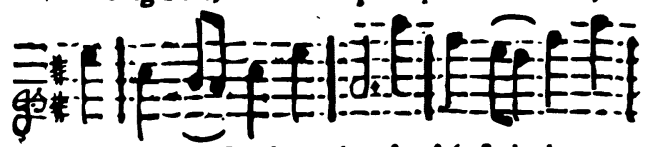

Thou on the lord $x-1$, , fo gefe Bale thou go

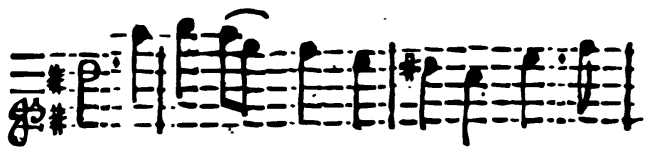

on; $6 x$ on bis Work thy Aed-fall Eye, fo

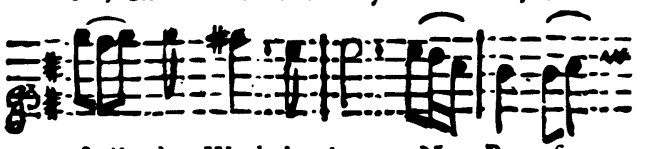

thall thy Work be done. No Pro-fit

A 3 cenfl

\section{Continued.}
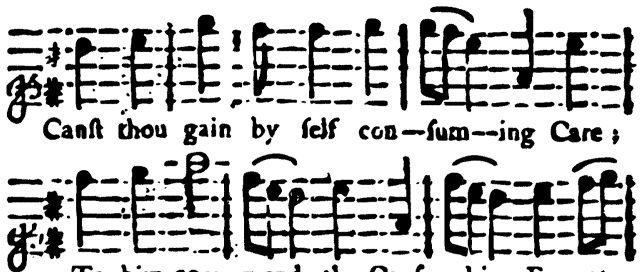
To hin com.-mend thy Caufe, his Far at-

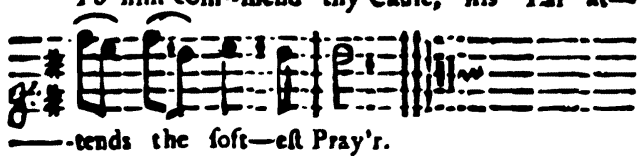

Figure 1: "Jericho Tune" from The Foundery Collection 
Hemdyke Tune. Vol. 2. Page 10x.

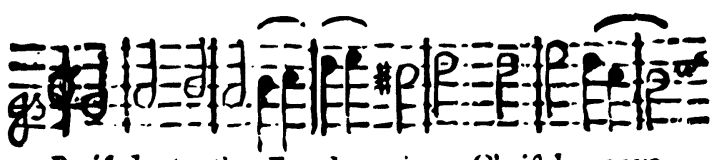

Praire be to the Fa..ther given, Chrif he gave

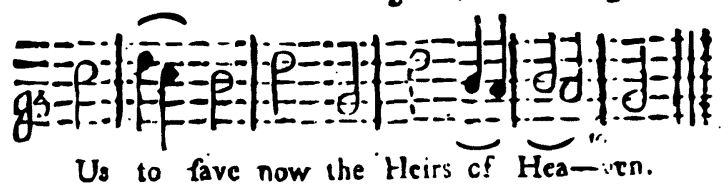

Figure 2: "Hemdyke Tune" from The Foundery Collection

syllables over several notes all contribute to the unlikelihood of this tune being successfully sung by congregations.

By contrast, "Hemdyke Tune" is brief and was clearly composed with the intention of congregational singing. Again, the time signature indicates a minim pulse, and Wesley's predilection for swift singing is well-recorded; ${ }^{25}$ however, the music progresses mainly in minims, which define the basic pulse, with crotchets used only as simple decoration; the melody is simple, contained within the range of a sixth, and generally progresses by step-wise movement. Although several syllables are extended, the clearly defined metrical phrase structure of the tune prevents the textual association from becoming incomprehensible. Tonally it is simple, indeed predictable, with an implied modulation to the dominant at the end of the first phrase, before a return to the tonic. Here, then, is a hymn tune immediately accessible to those who sing it, due to its concision, clarity and structure, which combine to grant primacy to the text, as was Wesley's theological intention. By including such tunes, Wesley is affirming their suitability for congregational use, thus making both a practical statement concerning the musical qualities of the tunes, and a theological statement concerning their accordance, and that of the associated texts, with the theological aims of Methodism.

To understand the theological significance of the understanding of hymnody, both text and music, as an evangelical tool of engagement

25 See "Directions for Singing" Sacred Melody (1761/5) in Carlton R. Young, Music of the Heart : John \& Charles Wesley on Music and Musicians (Carol Stream: Hope, 1995), 72-73. 
with those beyond the confines of the movement, Jon Michael Spencer's theoretical discussion of the hinterland between the Sacred and Secular in Theological Music: Introduction to Theomusicology $y^{26}$ may be profitably applied. Using an Augustinian model, Spencer sets out a series of connecting spheres: sacred, secular and profane; he describes the area common to the sacred and secular as "the mirror through which the sacred reflects aspects of the secular and the secular reflects aspects of the sacred. ${ }^{\prime 27}$ Furthermore, he comments that "it seems reasonable to suggest that if a particular music being performed or listened to is sacred, then it is an objectification of the deity's will embodied in the person. ${ }^{\prime 28} \mathrm{In}$ these terms, the influence of the Moravian understanding and use of hymnody on Wesley can be seen as using hymns in a way that embodies within itself the essence of the message being preached through the hymns themselves. Although the textual influences may be most easily accommodated within this discourse, there are also resonances with the musical influence of Moravian hymnody on Methodism. The stylistic qualities of the music, if not the precise repertoire, resembled secular musical forms, such as solo songs, more closely than traditional church genres, such as plainchant or polyphony. Furthermore, as the music was frequently composed specifically for use in worship and chosen to respond to a particular text through its tonal, harmonic, metrical or melodic characteristics, according to Spencer's argument, its peculiar combination with the text engenders within the believer who sings or hears it the particular religious sentiment of the hymn or a response to its exhortation; "In this regard, it seems reasonable to define sacred music as the musico-behavioral objectification of the will of the religious for the sole edification of the deity and those who maintain the sacred gathering place". ${ }^{29}$

The heightened significance of congregational hymnody as an evangelistic tool and the use of music as a medium for its communication can be interpreted within this model, for the unity of text and music was crucial in ensuring that the theological message was conveyed in a memorable fashion to those who sang and heard the hymns. The music becomes associated with a particular text, and by definition, the theo-

26 Jon Michael Spencer, Theological Music : Introduction to Theomusicology (New York: Greenwood Press, 1991).

27 Ibid, [35].

28 Ibid, 39.

29 Ibid. 
logical message contained therein. Thus, the singing of hymn takes on a heightened religious significance, both at an individual level and for the wider worshipping community. The appropriateness of tunes such as those learned from the Moravians for Methodist purposes may be understood in terms of Thomas and Manning's concept of "The Iconic Function of Music. ${ }^{\prime 30}$ They claim that music, properly suited to a particular religious function, can take on some of the qualities of the theological message it represents; referring to the use of plainchant in the Latin Mass, they argue that "The music is included in such a way that it harmonizes with the actions and the text and becomes part of the whole. ${ }^{\prime 31}$ Although the context of Methodist worship is rather different, the same principle applies: the music, chosen for ease of participation and used in conjunction with a particular theological message, becomes associated with the text and the religious and cultural environment of Methodist worship in a way that the hymn as a complete entity becomes significant to the believer and the purpose of the movement.

The significance of hymnody for the corporate worship within the movement as a whole is explained in theological terms by Brian Wren, who argues that the act of singing together both strengthens the individual's faith but also heightens their understanding of their part within the religious community at large: "For a congregation, its corporate song makes a theological statement: 'We are the body of Christ.'... Though we do not submerge our identity in the crowd, singing together brings us together, demonstrating how we belong to one another in Christ." ${ }^{32}$ This theological understanding is heightened when combined with the evangelistic nature of hymnody Wesley learned from the Moravians; as well as emphasizing unity within the established religious community, the act of singing hymns that espoused a theology of grace freely offered presented a means of incorporating new believers within the community.

Thus Moravian hymnody can be seen to have exerted both particular and general influences on Methodist practice, through the use of specific repertoire and also through theoretical principles, which may be interpreted as theologically significant for the movement's ethos and

30 Terence Thomas and Elizabeth Manning, "The Iconic Function of Music," in The Sense of the Sacramental : Movement and Measure in Art and Music, Place and Time, ed. David Brown and Ann Loades (London: SPCK, 1995).

31 Ibid, 163-64.

32 Brian A. Wren, Praying Twice: The Music and Words of Congregational Song (Louisville: Westminster John Knox P., 2000), 84-85. 
the furtherance of its work. From Wesley's intensely personal experience, which began during the voyage to Georgia, Methodist hymnody, in both material and concept, developed into a defining feature of the movement's theological standpoint, evangelical method, ethos and cultural and social engagement, reflecting the zeal for the Gospel with which Wesley set out for Georgia and drawing heavily on the practices and principles of the Moravian Christians with whom he came into contact in America, England and Germany. The resulting hymnody, both text and music, may be interpreted as a theological embodiment of the fruits of this relationship, which far exceeded the specific and short-lived immediate contact. Its ultimate significance to Wesley and thus for the Methodist movement as a whole may be seen in the last of his "Directions for Singing":

VII Above all sing spiritually. Have an eye to God in every word you sing. Aim at pleasing him more than yourself, or any other creature. In order to [do] this attend strictly to the sense of what you sing, and see that your Heart is not carried away with the sound, but offered to God continually; so shall your singing be such as the Lord will approve of here, and reward when he cometh in the clouds of heaven. ${ }^{33}$

\section{MARTIN V. CLARKE \\ Durham University}

33 Cited in Young, Music of the Heart: John E Charles Wesley on Music and Musicians, 72-73. 